\title{
Interactive Multimedia Based Mathematics Problem Solving to Develop Students' Reasoning
}

\author{
Mohammad Faizal Amir ${ }^{1}$, Fitria Nur Hasanah², Hamsyah Musthofa ${ }^{2}$ \\ ${ }^{1}$ Elementary School Teacher Education Department, Universitas Muhammadiyah Sidoarjo, Sidoarjo, Indonesia \\ ${ }^{2}$ Information Technology Education Department, Universitas Muhammadiyah Sidoarjo, Sidoarjo, Indonesia \\ *Corresponding author E-mail: faizal.amir@umsida.ac.id
}

\begin{abstract}
The progress of information and communication technology demands lecturer of mathematics to make innovative learning based on IT while focusing the main goal in learning mathematics, i.e to create students who are skilled in solving problems and have good mathematical reasoning. Therefore, an interactive mathematical development based on problem solving is required. The model is developed using ADDIE (Analysis, Design, Development, Implementation, Evaluation). The data is analyzed using both Quantitative (as the main data) and qualitative (as supporting data). The results showed that interactive mathematical multimedia significantly improved the students' mathematical reasoning in terms of analyzing data, proposing allegations, verifying, drawing conclusions, and examining the validity of arguments. Students' responsiveness and motivation to learn mathematics is also positive because multimedia has interactive video display and complete material, while students feel that the learning process is not limited by space and time.
\end{abstract}

Keywords: multimedia, problem solving, reasoning, mathematics

\section{Introduction}

The world has entered the era of the world's industrial revolution 4.0 when information technology is the base in human life [1][7]. In facing the challenges that come along this era, lecturers or faculty in college are required to adapt their teaching styles [8]-[10]. This is because IT and communication in learning play an important role to facilitate the delivery of materials by teachers to students[11], and its application can have a potential impact that can improve the quality of learning. One of the development of information technology is the birth of android operating system, ranging from gadgets, tablet PCs, smartphones, and other applications that have android operating system [4], [12]-[14]. Until May 2018, android users in Indonesia reach $65.9 \%$ of all smartphone users [15].

Mobile devices, especially android ones, have changed the functionality of communication tools into a tool for entertainment, and learning [16]. Learning through mobile or mobile learning has become part of the educative process. Smartphone with android operating system has been widely used in education, one of which is for the development of learning interactive multimedia [17], [18]. Interactive Multimedia is part of media [19]-[21], defined as the tools and materials have combination of the words (such as printed text or spoken text), picture (such as illustrations, animation, or video) [3], [19], [22]-[24] to support learning activity that can be used to achieve educational goals. Elementary School Teacher Education (PGSD) students feel boring and show low performance to the subject of Basic Mathematics Concepts [25]. Because in lectures, lecturers often use conventional speech and assignment methods along with white board as the multimedia [26]. Teaching Design that uses multimedia often becomes an effective learning approach in improving student skills [27]-[29]. Use of Android-based learn- ing in varians subject influence the increase in academic performance of learning motivation and cognitive learning outcomes [29]-[31]. The development of multimedia-based educational games can improve students' psychology aspects including students' motivation, interest, and attitude [32].

The National Council of Teachers of Mathematics (NCTM) stated that learning mathematics is designed to make students as problem solvers [33]-[35] who can deliver arguments mathematically [36]. The active involvement of students in exploring visual mathematical tasks[37] or problem solving task can help students to achieve high-level thinking and have good mathematical reasoning [38]-[40]. Therefore, interactive multimedia problem solving based on subjects of Basic Mathematical Concepts to improve students' reasoning is needed.

\section{Method}

This study uses two different methods, namely development research[41][42] to design interactive multimedia problem solving based, and experimental method with post-test only control group design[43] to determine the effectiveness of application of interactive multimedia problem solving based on improving students' reasoning. The development model used is Analysis, Design, Development, Implementation, Evaluation called ADDIE [44]. The steps of ADDIE development can be seen in Figure 1.

The subjects of the study were the students of the first year of the Elementary Teacher Education Department who took the course of Basic Mathematics Concept in the academic year 2017-2018 in Universitas Muhammadiyah Sidoarjo. The sample consists of 2 classes of 80 students selected at random. The A1 class is selected as the experiment class, while the A2 class is selected as the control class. The Posttest Only Control Group 
Design is done by giving posttest, without pretest in experiment and control class [43], class A1 as control class was given treatment, while class A2 as control class was not during one semester (14 meetings).

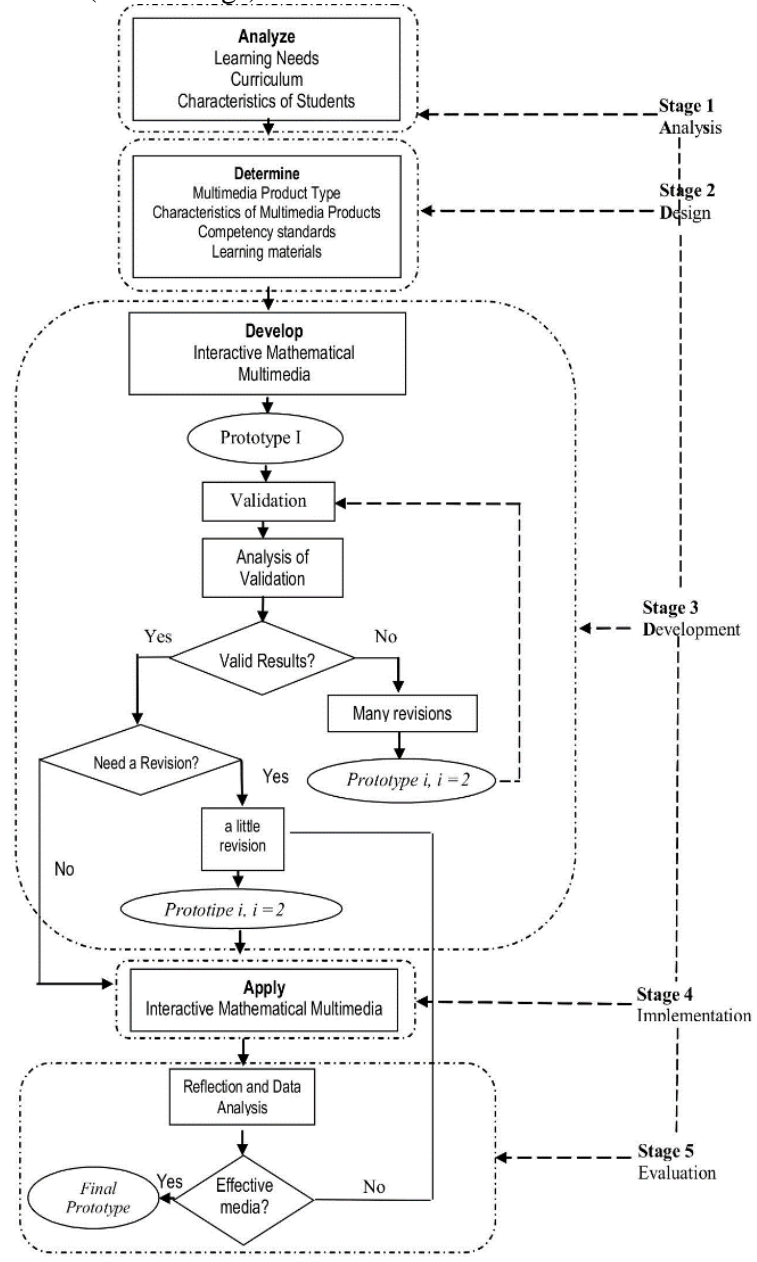

Fig.1: ADDIE Development Procedure

The main data of this research is quantitative data covering percentage of expert validator value, questionnaire percentage, problem solving value, and student reasoning value, It is supported by qualitative descriptive data concerning student behavior during research process [45]. These behaviors include learning activities, motivation, performance problem solving, and perormance reasoning. The effectiveness of multimedia treatment was analyzed using t-test separed paired variance (2 sided) with the following formula[43].

$$
t=\frac{\bar{x}_{1}-\bar{x}_{2}}{\sqrt{\frac{s_{1}^{2}}{n_{1}}+\frac{s_{2}^{2}}{n_{2}}}}
$$

\section{Methodology Research}

The research object is a supply chain for fish products produced by SMEs. Specifically selected fish products are fish crackers. The research was conducted in East Java, Indonesia. Data collection is conducted through observation and interviews with SMEs entrepreneurs.

The study was conducted through three stages: risk identification, risk measurement and risk prioritization. The process business used in the supply chain refers to the SCOR (Supply chain operation Reference) concept with the following research framework [46].

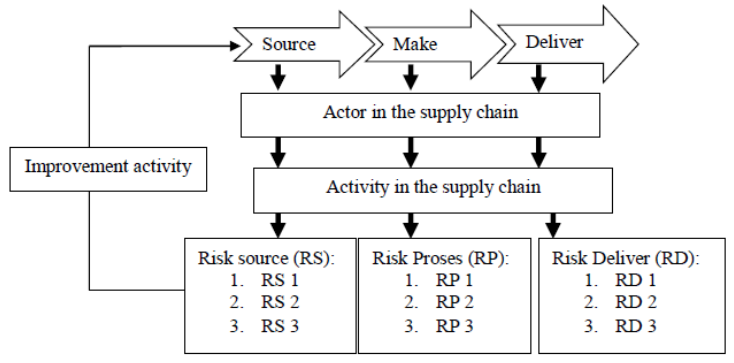

Fig.2: Research framework [46]

a. Identify risk event

At this stage will be identification of various types of risk event in the supply chain of fish crackers. Identify the type of event ricks performed for each stage of the business process (source, make, deliver).

b. Risk measurement

This stage is done to know the impact of risk event. Measurements begin with assessing likelihood (L) and, impact (I). Assessment is done by experts who know the food safety system on the supply chain of fish crackers, with a scale of 1-10.

c. Determination risk score (RS)

The RPV shows the value of the impact of the risk event. $\mathrm{RPV}$ is obtained by the equation:

$\mathrm{RS}=\mathrm{IxL}$

Furthermore, RPV ranking will be conducted to determine the priority of risk. RPV can be used by decision makers to establish strategic steps of risk elimination

\section{Results and Discussion}

This multimedia design is developed based on the very familiar design, Polya Problem Solving indicator, which consist of understanding the problem, devising a plan, carrying out the plan, looking back [47]. The students' mathematical reasoning abilities are measured by indicators in terms of analyzing data, presenting, verifying, and drawing conclusions [37], [48]. Further sub indicator is presented in Table 1.

Table.1: indicators to measure mathematical reasoning

\begin{tabular}{|c|c|c|}
\hline No. & Reasoning Indicator & Sub-indiCator \\
\hline \multirow{3}{*}{1} & \multirow{3}{*}{ Analyze the Data } & $\begin{array}{l}\text { a. Identifying every factors and facts in } \\
\text { the problem }\end{array}$ \\
\hline & & $\begin{array}{l}\text { b. Analyzing problem in the question, } \\
\text { either in its pattern or its relation }\end{array}$ \\
\hline & & $\begin{array}{l}\text { c. Understanding what is lknown and } \\
\text { asked in the question }\end{array}$ \\
\hline \multirow{3}{*}{2} & \multirow{3}{*}{$\begin{array}{l}\text { Proposing } \\
\text { Assumption } \\
\text { (conjecture) }\end{array}$} & $\begin{array}{l}\text { a. Deciding mathematical charateristics } \\
\text { in the problem based on knowledge }\end{array}$ \\
\hline & & b. Proposing conjecture \\
\hline & & c. Making alternative conjecture \\
\hline \multirow[t]{2}{*}{3} & \multirow[t]{2}{*}{$\begin{array}{l}\text { Proving or } \\
\text { Making } \\
\text { Justification }\end{array}$} & $\begin{array}{l}\text { a. Developing mathematical argument } \\
\text { with mathematical calculation } \\
\text { matching with calculated assumption } \\
\text { as in the conjecture }\end{array}$ \\
\hline & & $\begin{array}{l}\text { b. Processing calculation process as the } \\
\text { steps stated in the conjecture }\end{array}$ \\
\hline \multirow{2}{*}{4} & \multirow{2}{*}{$\begin{array}{l}\text { Drawing } \\
\text { Conclusion }\end{array}$} & \begin{tabular}{|lll} 
a. Drawing conclusion based on \\
developed argument/ statement
\end{tabular} \\
\hline & & $\begin{array}{l}\text { b. presenting result by giving logical } \\
\text { and true evidence }\end{array}$ \\
\hline \multirow{3}{*}{5} & \multirow{3}{*}{$\begin{array}{l}\text { Checking the } \\
\text { Validity of the } \\
\text { argument }\end{array}$} & $\begin{array}{l}\text { a. Checking every steps in the } \\
\text { verification process }\end{array}$ \\
\hline & & $\begin{array}{l}\text { b. Checking every answers in the } \\
\text { verification process }\end{array}$ \\
\hline & & $\begin{array}{l}\text { c. Composing valid argument to support } \\
\text { evidences of conjecture. }\end{array}$ \\
\hline
\end{tabular}


The multimedia mathematics was developed using Adobe CS6 adobe flash software, Adobe AIR 24.0.0.180, Java Development kit $8 \mathrm{u} 45$, and Android SDK. The minimum hardware requirement for development is the IntelCore i3 processor, $4 \mathrm{~Gb}$ RAM. The interactive multimedia application requires Android ICS or higher with minimum hardware specification 1Gb RAM. At the stage of product design, the researcher performs several processes, namely layout design, designing story board, content contents, and instructions of use.

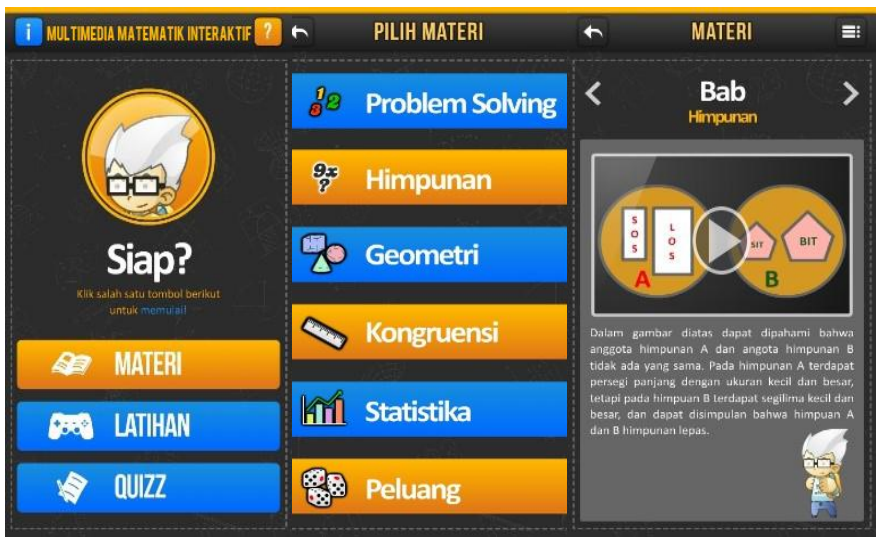

Fig.3: Multimedia Home, Content Options, Video Visualization, Content Explanation

The "Content" button serves to open menus on various subject materials to be studied around mathematics. The "exercise" button serves to provide a list of material to be covered. Quizz button functions to evaluate the performance of mathematical reasoning for 2 times that is the 8th meeting at middle exam Semester and 16th meeting at the final exam of Semester. In the material section, a brief description of each sub-material will be presented. The material is presented in an interesting and interactive manner with various animations as well as videos.

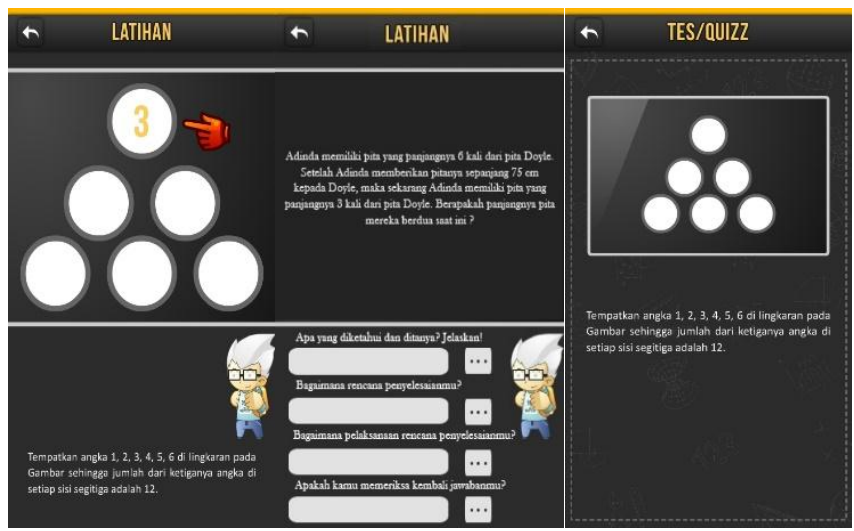

Fig.4 Image of Problem Solving Drill and Reasoning Test

The "exercise" menu serves to deepen and simulate questions about mathematics-based problems solving polya for 14 meetings, to keep the use of multimedia in control. The exercise menu on the next material will not be accessible to the student if the student has not uploaded the problem solving exercise answer on the previous material.

The "Quizz" section is intended as an evaluation tool for mathematical reasoning. The first quiz conducted during the Middle Examination Semester covers material problem solving, set, and geometry. While the second quiz is done when the Final Exam Semester covers material congruence, statistics, and opportunities. The student posttest score is taken from the average of the Middle Semester Exam and the End of Semester as the value of mathematical reasoning.

Multimedia validity is verified based on aspects of functionality, usability, efficiency, portability, and learning content [32]. Functionality, efficiency, portability verified by 3 lecturers of multimedia experts, learning content verified by 3 lecturers of mathematics education, while aspects verified by 35 Elementary Education Department students in the second half of academic year 2016-2017 who have taken the subject of mathematical concepts. Multimedia verification results can be seen in table 2 .

Table.2: The result of interactive mathematics multimedia validation

\begin{tabular}{|l|l|l|l|}
\hline No. & Aspects & Percentage & Criteria \\
\hline 1 & functionality & $86 \%$ & Very Good \\
\hline 2 & usability & $83 \%$ & Very Good \\
\hline 3 & efficiency & $88 \%$ & Very Good \\
\hline 4 & portability & $80 \%$ & Good \\
\hline 5 & learning content & $85 \%$ & Very Good \\
\hline \multicolumn{2}{|l|}{ Average } & $84 \%$ & Very Good \\
\hline
\end{tabular}

Table 2 shows that the percentage of multimedia quality in all aspects above is $80 \%$ in the very good category. The average percentage is at $84 \%$ (very good), which means that interactive mathematical multimedia is worth of problem solving based and has good quality to improve students' reasoning.

To identify the effectiveness of the use of multimedia, the results of drill problem solving for 14 meetings, the students' posttest reasoning scores based on the mean value of the Middle Semester Exam, and the final exam score were analyzed for the experimental and control classes. The average result of problem solving per Polya indicator is presented in figure 4, 5, 6, 7, while the average result of student posttest score can be seen in figure 8.

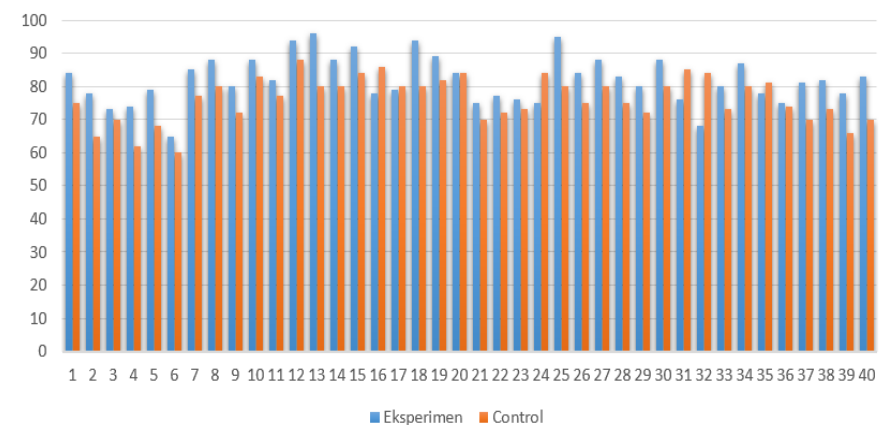

Fig.5: Understanding the Problem

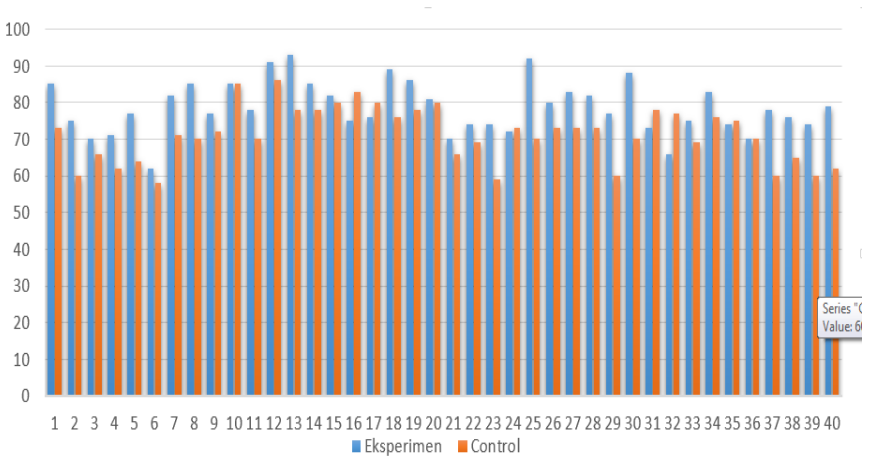

Fig.6: Devising a Plan

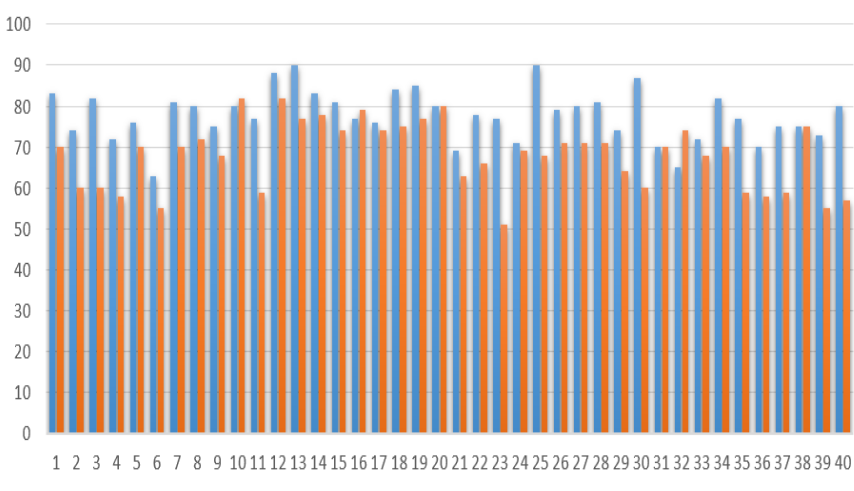

- Eksperimen - Contro

Fig.7: Carrying Out The Plan 


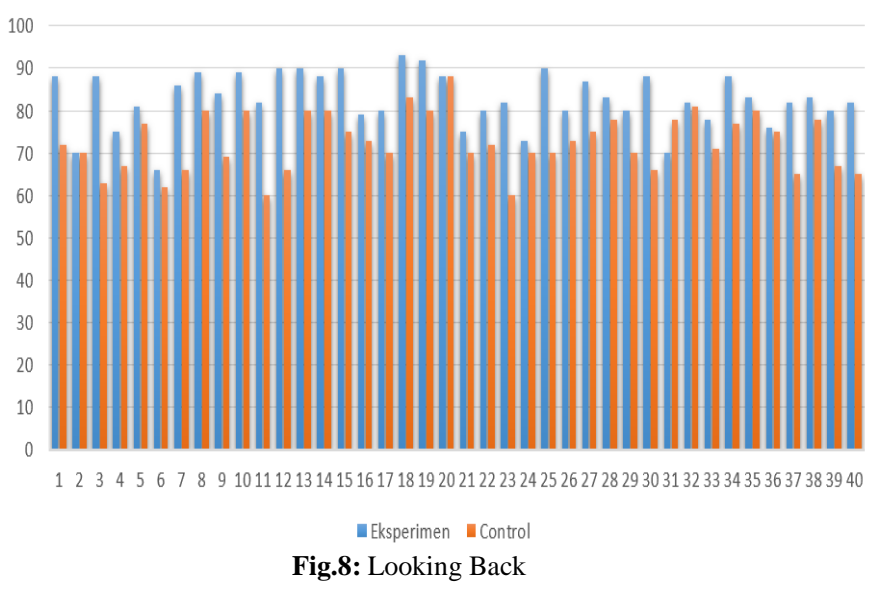

Based on the ilustrations, it can be interpreted that, generally, the problem solving ability of students per indicator in the experimental class performed by the implementation of multimedia is higher than the control class that does not apply multimedia. The habituation through drill program of problem solving through multimedia has an impact on improving student's reasoning performance [49]. The detailed quantitative illustration of paired sample t-test test result can be see in Table 3 .

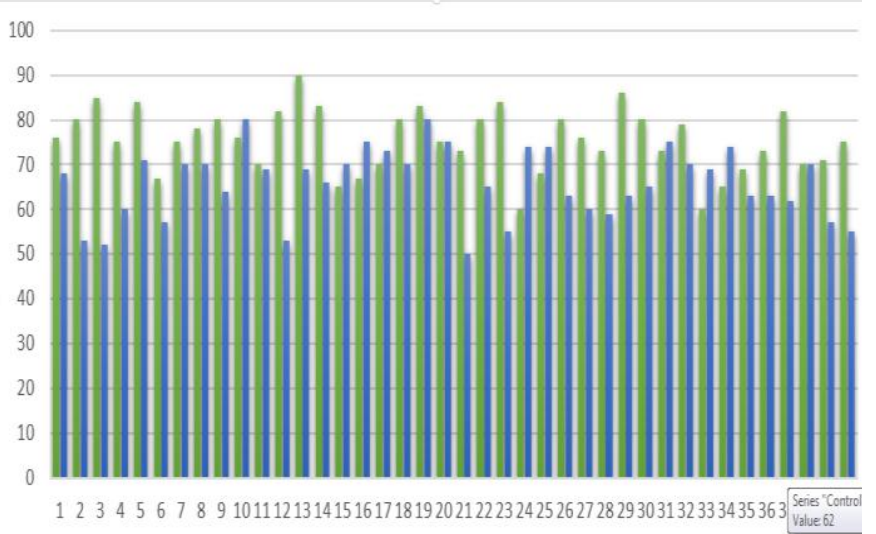

wEksperimen $=$ Control

Fig.9: Reasoning Matematic

Table.3: T-Test Calculation Result

\begin{tabular}{|l|l|l|l|l|l|}
\hline Class & $\mathrm{N}$ & Mean & Dev Std & $\mathrm{t}$ test & t-table \\
\cline { 1 - 5 } Experiment & 40 & 75,45 & 7,11 & 5,79 & 2,00 \\
\cline { 1 - 3 } Control & 40 & 65,78 & 7,84 & & \\
\hline
\end{tabular}

Table 3 shows that the experiment class average is higher than the control class $(75,45>65,78)$. T-test of separed paired variance t-test also obtained higher than $\mathrm{t}$ table $\alpha=5 \%=0,05(5,79$ $>2,00)$. This shows that learning by using problem solvingbased mathematical multimedia has significant effect to improve students' reasoning.

Students' response upon learning after using multimedia is $87 \%$ in the positive category. By using this multimedia, problem solving performance improves consistently [49], and encourages to students to try solving mathematical problems both inside and outside the classroom either collaboratively or individually[27]. This activity has also helped students to be more focused, effective, efficient, able to solve problems using variative strategies and thoroughly, critical in analyzing data and making conjecture, verification, drawing conclusions, and check the validity of arguments logically based on relevant information and scientific facts [50]. Students' motivation in learning mathematics is also at positive stage [51]. Through the multimedia, they have a visual image of what will be learned via vid and students feel freely because they do not need to bring books or excessive reading material because most of the information has been provided. It means that that more energy can be provided and focused on problem solving [52]. The troubles solving process can be done when they are out of class or during leisure time anywhere.
Lastly, the multimedia can be a reference for educators to facilitate and help students effectively, practically, and efficiently, and also improve problem solving skills as well as students' reasoning abilities.

\section{Conclusion}

The developing of interactive mathematical multimedia based on polya problem solving indicator helps students to consistently practice the problem solving, either collaboratively or individually, and flexibelly, either inside or outside the classroom. Students become more focused, effective, efficient, thorough, critical, and creative in solving problems with different variance of strategies solving. Positive problem solving performance in using multimedia has a significant impact on students' mathematical reasoning in terms of analyzing data, suggesting, verifying, drawing conclusions, and checking the validity of arguments. Students' responsiveness and motivation to learn mathematics is also positive because multimedia has an interactive video display, complete material, and students feel learning is not burdened to any space and time.

\section{References}

[1] F. Shrouf, J. Ordieres, and G. Miragliotta, "Smart factories in Industry 4.0: A review of the concept and of energy management approached in production based on the Internet of Things paradigm," in 2014 IEEE International Conference on Industrial Engineering and Engineering Management, 2014.

[2] K. Adiyarta, D. Napitupulu, H. Nurdianto, R. Rahim, and A. Ahmar, "User acceptance of E-Government Services Based on TRAM model," IOP Conf. Ser. Mater. Sci. Eng., vol. 352, p. 012057, May 2018.

[3] S. Sriadhi, R. Rahim, and A. S. Ahmar, "RC4 Algorithm Visualization for Cryptography Education," J. Phys. Conf. Ser., vol. 1028, no. 1, p. 012057, Jun. 2018.

[4] D. Napitupulu, M. Syafrullah, R. Rahim, D. Abdullah, and M. Setiawan, "Analysis of user readiness toward ICT usage at small medium enterprise in south tangerang," J. Phys. Conf. Ser., vol. 1007, no. 1, p. 012042, Apr. 2018.

[5] Rusli, N. Noni, N. Ihsan, and A. S. Ahmar, "The Development of Research Management Information System Based on Web at Universitas Negeri Makassar," J. Phys. Conf. Ser., vol. 1028, no. 1, p. 012050, 2018.

[6] D. Lazim et al., "Information Management and PSM Evaluation System," Int. J. Eng. Technol., vol. 7, no. 1.6, pp. 17-19, 2018.

[7] A. S. Ahmar and R. Jefri, "The development of information system of IT-Based scientific works to improve the quality of the students' final project publication," J. Phys. Conf. Ser., vol. 1028, no. 1 , p. 012047,2018

[8] A. S. Ahmar et al., "Lecturers ' Understanding on Indexing Databases of SINTA, DOAJ, Google Scholar, SCOPUS, and Web of Science: A Study of Indonesians," J. Phys. Conf. Ser., vol. 954, no. 1, p. 012026, 2018.

[9] R. Rahim et al., "TOPSIS Method Application for Decision Support System in Internal Control for Selecting Best Employees," J. Phys. Conf. Ser., vol. 1028, no. 1, p. 012052, Jun. 2018.

[10] K. Adiyarta, D. Napitupulu, R. Rahim, D. Abdullah, and M. Setiawan, "Analysis of e-learning implementation readiness based on integrated elr model," J. Phys. Conf. Ser., vol. 1007, no. 1, p. 012041, Apr. 2018.

[11] D. Napitupulu et al., "Analysis of Student Satisfaction Toward Quality of Service Facility,” J. Phys. Conf. Ser., vol. 954, no. 1, 2018.

[12] T. Listyorini and R. Rahim, "A prototype fire detection implemented using the Internet of Things and fuzzy logic," World Trans. Eng. Technol. Educ., vol. 16, no. 1, pp. 42-46, 2018.

[13] A. S. Ahmar and A. Rahman, "Development of teaching material using an Android," Glob. J. Eng. Educ., vol. 19, no. 1, 2017.

[14] A. Rahman, U. Mulbar, and A. S. Ahmar, "Development of Webbased Logical Thinking Abilities and Android as an Alternative Solution for Research Instruments," J. Phys. Conf. Ser., vol. 1028 no. 1 , p. 012168, 2018.

[15] StatCounter, "Top 8 mobile \& tablet operating systems in 
Indonesia from May 2017 to May 2018.”.

[16] D. D. Kim, D. Rueckert, D. D. Kim, and D. Seo, "Students Perceptions and Experiences of," vol. 17, no. 3, pp. 52-73, 2013.

[17] J. Simarmata, A. Djohar, J. Purba, and E. A. Juanda, "Design of a Blended Learning Environment Based on Merrill's Principles," $J$. Phys. Conf. Ser., vol. 954, p. 012005, Jan. 2018.

[18] N. Arsyad, A. Rahman, and A. S. Ahmar, "Developing a selflearning model based on open-ended questions to increase the students' creativity in calculus," Glob. J. Eng. Educ., vol. 19, no. 2, 2017.

[19] S. Mishra and R. C. Sharma, Interactive multimedia in education and training. Igi Global, 2004.

[20] M. A. Rosid, A. Rachmadany, M. T. Multazam, A. B. D. Nandiyanto, A. G. Abdullah, and I. Widiaty, "Integration Telegram Bot on E-Complaint Applications in College," IOP Conf. Ser. Mater. Sci. Eng., vol. 288, no. 1, p. 12159, 2018.

[21] R. Rahim, A. S. Ahmar, A. P. Ardyanti, and D. Nofriansyah, "Visual Approach of Searching Process using Boyer-Moore Algorithm," J. Phys. Conf. Ser., vol. 930, no. 1, p. 012001, Dec. 2017.

[22] R. E. Mayer, The Cambridge handbook of multimedia learning. Cambridge university press, 2005.

[23] R. Rahim, I. Zulkarnain, and H. Jaya, "A review: search visualization with Knuth Morris Pratt algorithm," in IOP Conference Series: Materials Science and Engineering, 2017, vol. 237, no. 1, p. 012026.

[24] Sriadhi, "Model of the Material Inventory Management Using Multimedia based Information System," in IOP Conference Series: Materials Science and Engineering, 2017, vol. 180, no. 1.

[25] M. F. Amir, "Identifikasi Kesulitan Mahasiswa Dalam Memecahkan Masalah Open Ended Materi Nilai Mutlak," $J$. Mercumatika J. Penelit. Mat. dan Pendidik. Mat., vol. 2, no. 2, pp. 1-15, 2017.

[26] W. Y. Hwang, N. S. Chen, and R.L. Hsu, "Development and evaluation of multimedia whiteboard system for improving mathematical problem solving," Comput. Educ., vol. 46, no. 2, pp. 105-121, 2006.

[27] D. Zhang, "Interactive multimedia-based e-learning: A study of effectiveness," Am. J. Distance Educ., vol. 19, no. 3, pp. 149-162, 2005.

[28] M. Maag, "The effectiveness of an interactive multimedia learning tool on nursing students' math knowledge and self- efficacy," CIN Comput. Informatics, Nurs., vol. 22, no. 1 pp. 26-33, 2004

[29] S. D. Sorden, "A Cognitive Approach to Instructional Design for Multimedia Learning," Informing Sci. J., vol. 8, pp. 263-279, 2005.

[30] R. Godwin-jones, "Emerging Technologies Mobile Apps for Language Learning," Lang. Learn. Technol., vol. 15, no. 2, pp. 2-11, 2011.

[31] Hafizul Fahri Hanafi and Khairulanuar Samsudin, "Mobile learning environment system ( MLES ): The case of Androidbased learning application on undergraduates ' learning," Int. J. Adv. Comput. Sci. Appl., vol. 3, no. 3, pp. 1-5, 2012.

[32] N. Nasrudin, I. Agustina, A. Akrim, A. S. Ahmar, and R. Rahim, "Multimedia educational game approach for psychological conditional," Int. J. Eng. Technol., vol. 7, no. 2.9, pp. 78-81, 2018.

[33] M. Niss, B. Regina, P. Núria, T. Ross, and J. A. V. Ochoa, "Survey team on: conceptualisation of the role of competencies, knowing and knowledge in mathematics education research," ZDM Math. Educ., vol. 48, no. 5, pp. 611-632, 2016.

[34] A. Rahman and A. S. Ahmar, "Exploration of mathematics problem solving process based on the thinking level of students in junior high school," Int. J. Environ. Sci. Educ., vol. 11, no. 14 pp. 7278-7285, 2016.

[35] U. Mulbar, A. Rahman, and A. S. Ahmar, "Analysis of the ability in mathematical problem-solving based on SOLO taxonomy and cognitive style," World Trans. Eng. Technol. Educ., vol. 15, no. 1 pp. $68-73,2017$.

[36] A. J. B. Hutauruk, "Literature Review: Trends of Matematical Competences and Learning Activity Literature Review: Trends of Matematical Competences and Learning Activity," in Seminar Pendidikan Matematika SPs UPI 2016, 2017, no. April, pp. 274 284.

[37] E. Debrenti, "Visual Representations In Mathematics Teaching: An Experiment With Students," Acta Didact. Napocensia, vol. 8, no. 1 , pp. 21-26, 2015

[38] M. Henningsen and M.K. Stein, "Mathematical tasks and student cognition: Classroom-based factors that support and inhibit high- level mathematical thinking and reasoning," J. Res. Math. Educ., vol. 28, no. 5, pp. 524-549, 1997

[39] A. Rahman and A. S. Ahmar, "Relationship between learning styles and learning achievement in mathematics based on genders," World Trans. Eng. Technol. Educ., vol. 15, no. 1, pp. 74-77, 2017.

[40] M. Rais, F. Aryani, and A. S. Ahmar, "The influence of the inquiry learning model and learning style on the drawing technique of students," Glob. J. Eng. Educ., vol. 20, no. 1, pp. 64-68, 2018

[41] J. van den Akker, "Principles and Methods of Development Research," in Design approaches and tools in education and training, 1999 , pp. 1-14

[42] A. Rachmadany et al., "Classification of Indonesian quote on Twitter using Naïve Bayes," IOP Conf. Ser. Mater. Sci. Eng., vol. 288, no. 1, p. $12162,2018$.

[43] Sugiyono, Metode Penelitian Kuantitatif, kualitatif dan $R \& D$ 2013.

[44] M. Molenda, “ADDIE Model Design Development Implementation," no. June, pp. 34-36, 2003.

[45] S. Arikunto, Prosedur Penelitian. Jakarta: Rineka Cipta, 2012

[46] U. C. H.C. Wahyuni, I. Vanany, "Identifying risk event in Indonesian fresh meat supply chain Identifying risk event in Indonesian fresh meat supply chain," Mater. Sci. Eng., vol. 337 2018.

[47] G. Polya, "How to Solve it. A new aspect of mathematical method 2nd. edition." Princeton University Press, 1973.

[48] I. V. S. Mullis, M. O. Martin, and L. Jones, "Third International Mathematics and Science Study (TIMSS)," in Gunstone R. (eds) Encyclopedia of Science Education, Springer, Dordrecht, 2015, pp. 1075-1079.

[49] B. Hoffman and D. Ritchie, "Using multimedia to overcome the problems with problem based learning," Instr. Sci., vol. 25, no. 2, pp. 97-115, 1997.

[50] S. Bahrami and V. S. Yazdi, "Design and Production of Multimedia Training Programs for Problem Solving Skill and its Effect on the Mental Health of High School Female Students in Kermanshah," J. Asian Sci. Res., vol. 4, no. 12, pp. 784-798, 2014.

[51] E. Erhel, S. Jamet, "Digital game-based learning: Impact of instructions and feedback on motivation and learning effectiveness," Comput. Educ., vol. 6, no. 7, pp. 156-167, 2013.

[52] N. S. Hong, S. McGee, and B. C. Howard, "Essential components for solving various problems in multimedia learning environments," Апnu. Meet. Am. Educ. Res. Assoc., pp. 1-6, 2001. 